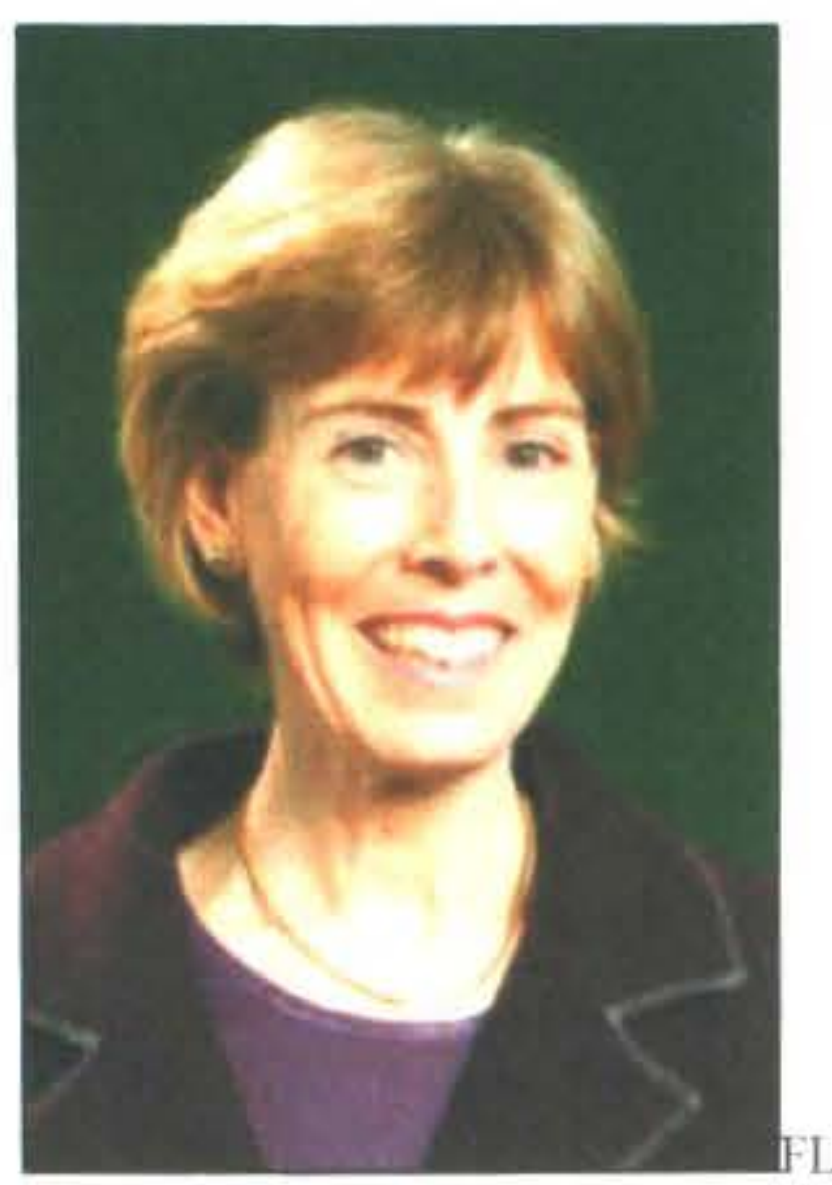

\title{
IMPROVING PRODUCTIVITY THROUGH ENHANCING EMPLOYEE WELLBEING AND PARTICIPATION
}

\author{
Ray Markey, Candice Harris, Felicity \\ Lamm, Stefan Kesting, Katherine \\ Ravenswood, Gay Simpkin \& David \\ Williamson
}

Auckland University of Technology

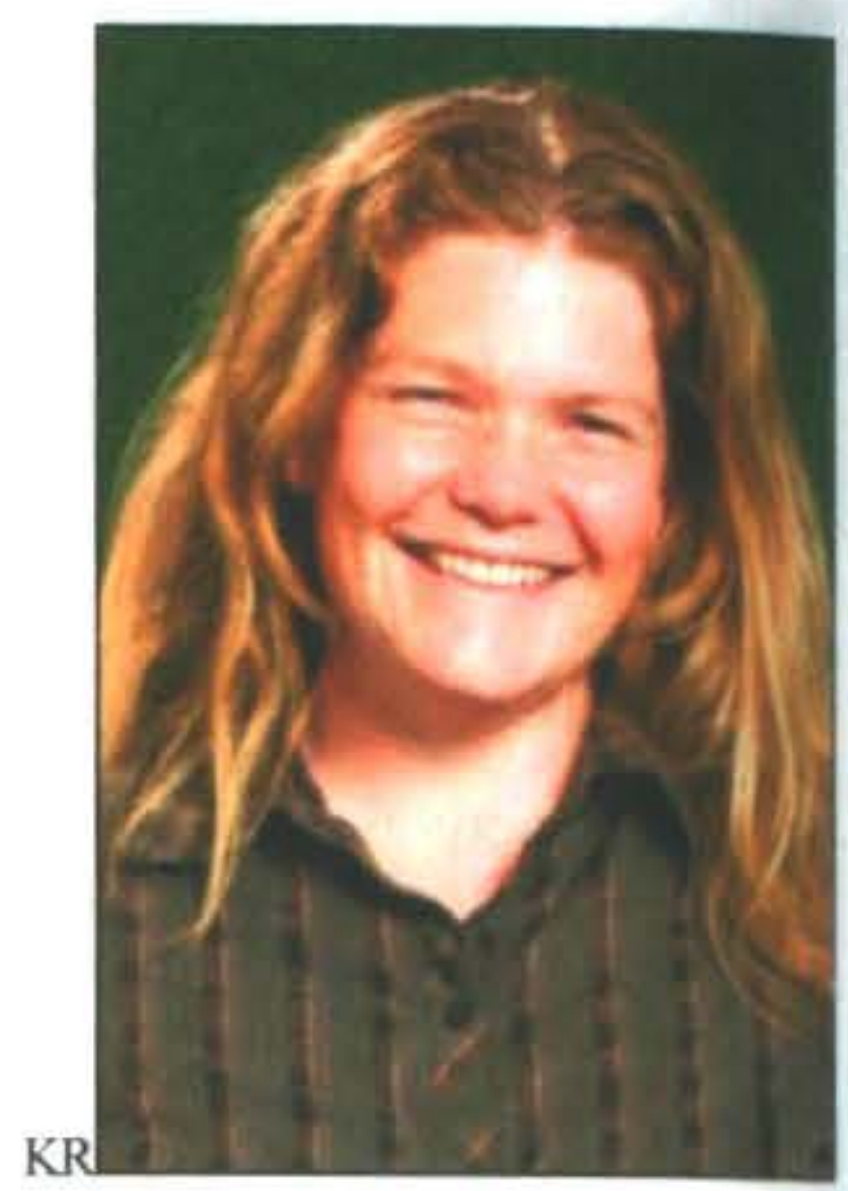

\section{Abstract}

This paper outlines the rationale and methodology for an international comparative project investigating the links between workplace productivity and employee wellness and well being via the operation of representative employee participation structures in Denmark and New Zealand. It will define and discuss the often contentious terms of productivity, wellbeing and participation and how employee participation and wellbeing and the work environment impact on productivity. This paper employs a multi-dimensional theoretical framework and will assess the significance of the issues examined: analyse the impact of employment practices and quality of the work environment on productivity: and as a result present the methodology developed for the project.

\section{Introduction}

There has been increasing interest in improving workplace performance to increase productivity in a context of increased global competitiveness. A growing body of evidence also indicates the impact of the work environment on organisational productivity as well as broad economic and social benefits of employment practices which contribute to employee wellness and well-being (Oxenburgh et al. 2004; Pocock 2003; Quinlan et al. 2001; WorkUK Survey 2005:). At the same time substantial evidence over a long period suggests that one specific employment practice, employee participation, impacts directly and positively on organisational performance and the broader work environment (Markey 2001). However, these three elements wellbeing, participation and productivity have rarely been brought together in research endeavours.

Productivity, employee well-being, and employee participation separately comprise major issues of public policy in both New Zealand and Denmark. New Zealand has faced low productivity growth for 30 years. Denmark has also experienced low productivity growth although over a shorter period of about 10 years (Iverson \& Riishøj 2007: 3). The Department of Labour in New Zealand has identified key drivers of productivity. including increasing productivity with currently available resources, in other words employees. One identified means of increasing employee productivity is through a positive workplace culture. This is one in which employees feel valued and participate in the organisation (DOL 2008). Employee participation has also been encouraged by Health and Safety legislation in
New Zealand. Under the Health and Safety in Employment Amendment Act 2002 organisations of more than 30 employees are required to have a health and safety employee participation system.

Employee participation and regulation of the working environment occur through two different but potentially interrelated processes:

- law-based regulation and Occupational Health and Safety (OHS) delegates, focusing on physical disease/injury;

- agreement-based participative structures (in New Zealand joint consultative committees (JCCs) and in Denmark cooperation committees). Agreement based participative structures focus more broadly on productivity and the work environment, including psycho-social issues affecting wellness/well-being.

In Denmark the broader structure of representative participation through cooperation committees is specifically concerned with the issues of productivity and the general work environment. It has been observed frequently in international literature that OHS committees of the New Zealand kind may broaden their jurisdiction beyond narrow conceptions of OHS (Bernard 1995; Knudsen 1995; Jecchinis 1997; Walters et al. 1993, 2005) however, their broader potential is generally not evaluated. In practice it is difficult to separate health and safety from work-life and other broad work environment issues, particularly involving the rising coincidence of employee stress and longer working hours (Lamm 2002), or the introduction of new technology or organisational change (Heller 1998). 


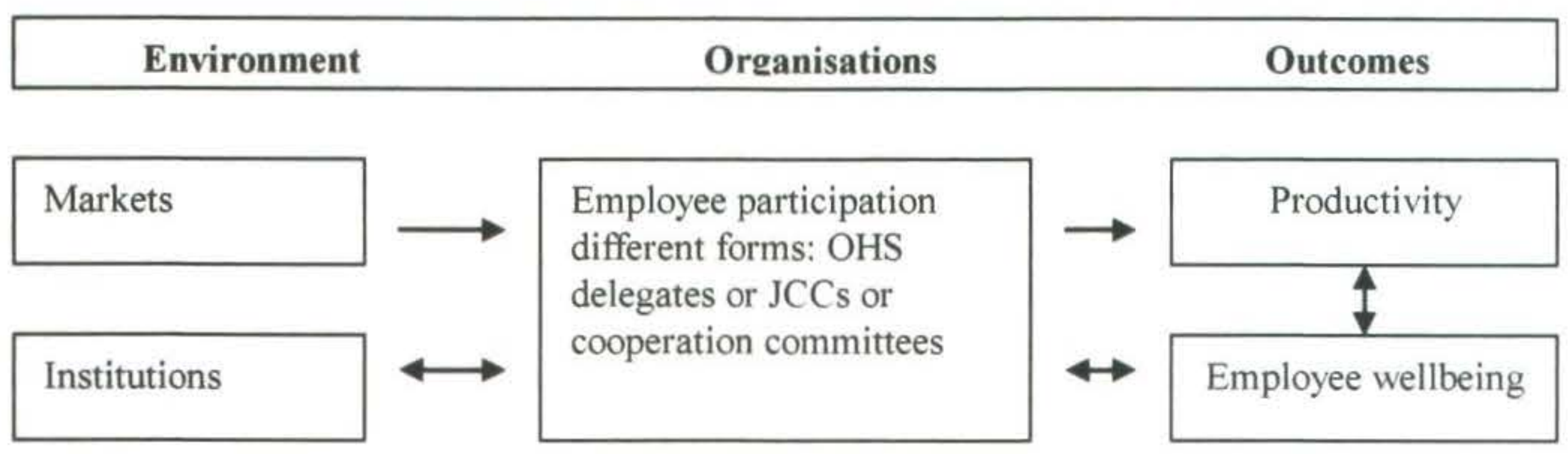

The research project will investigate the link between employee wellbeing, participation and productivity. It will examine the impact of participative structures on productivity and rates of occupational injury and disease (including stress) and work-life balance as expressions of employee wellness. The links between these issues amplify their individual significance. The project's integration of all these streams (see figure 1 above) for the first time represents a significant innovation in research. Both Denmark and New Zealand have small economies and legislation for health and safety delegates, but in New Zealand wider participative practices are not well developed by legislation or employer/union agreement as in Denmark. The comparison between the two countries will enable the research teams to test the impact of these wider practices on outcomes.

The remainder of this paper will analyse the terms work environment, employee participation and productivity. It will then examine how these three factors interact with and upon each other and finally present the methodology to be used by the research project.

\section{Work environment, employee well-being and representative employee participation}

Some critical contributors to the work environment, notably work-life balance and occupational health and safety (OHS), have been major policy concerns in New Zealand and Denmark, often linked with productivity. For the New Zealand Department of Labour work-life balance, OHS and productivity are the three key issues in policy development and implementation. OHS and worklife balance along with employee commitment are factors that in combination contribute to employee wellbeing (Baptiste 2008; Macky \& Boxall 2008). Implementing workplace policies that promote an employee friendly environment is commonly assumed to increase business performance, and particularly profitability (Faleye \& Trahan 2006; Harter, Schmidt and Keyes 2002; Lau 2000; Patterson, West, Lawthorn \& Nickell 1997). Lau's (2000) model suggests that high quality services within organisations increase employees' satisfaction, retention and productivity leading to greater external service value. Greater external value increases customer satisfaction and loyalty creating more revenue and higher profitability. Lau's model mostly relates to service industries which is significant for research in New Zealand as research in the service sector is scarce (New Zealand Tourism Institute). Key organisational policy areas which contribute significantly to the work environment include: work-life balance and flexible (family-friendly) job arrangements, training and health promotion. How and why wellbeing and participation are significantly linked with the work environment and productivity are outlined below.

Work-life balance has assumed importance for New Zealand because its employees work some of the longest hours in the OECD, second only to Iceland: 19 per cent work over 50 hours per week, 40 per cent work more than 45 hours per week and 10 per cent are multiple job holders. Part-time workers, who comprise over a quarter of the workforce, are included in these statistics (DoL 2006). Low unemployment of 3.6 per cent, and skills shortages, accentuate the problem. Although Denmark has enjoyed shorter working hours, there appears to be pressure on this practice because of declining productivity growth (OECD 2005). Arguments supporting family-friendly arrangements mostly focus on relationship improvement between employers and employees, enhancement of mutual trust, increasing job satisfaction and eventually business productivity (Akerlof \& Yellen 1986). Work-life balance and family-friendly workplaces have demonstrated links with productivity because of the impact on labour recruitment, retention and human resource costs (Markey \& Shulruf 2008; Yasbek 2004).

New Zealand's occupational injury and illness rates are poor. In 2004 the estimated cost of occupational injury and disease accounted for 4-8 per cent of New Zealand's GDP (Pearce et al. 2004). Denmark's occupational accident and fatality rates, 2561 and 3.4 respectively per 100,000 workers, are close to those for New Zealand (2699 and 3.5), and exceed those for European neighbours such as Sweden, Norway and the United Kingdom (Hamalainen et al. 2006), Dorman (2000) estimated that the associated costs accounted for 2.7 per cent of Danish GDP. Health promotion programmes at any of primary (preventive), secondary (when event occurs), or tertiary (remedial) levels are perceived as important tools to improve employee physical and mental health as well as workplace productivity (Aldana 2001; Chapman 2005; Grawitch et al 2006; Grawitch, Trares \& 
Kohler 2007; Tetrick \& Quick 2001). There is mounting evidence of huge cost relating to occupational health risks (Burton, Conti, Chen, Schultz \& Edington 1999; Dorman 2000; Pearce et al 2004; Toohey, Borthwick \& Archer 2005). Furthermore, a recent study reports that satisfaction with healthy workplace practices can predict employee outcomes, suggesting that it is not only what practices are actually put in place, but also employees perceptions about these practices that matter (Grawitch et al 2007).

Workplace health and safety risks have the potential to be very costly for organisations (Burton, Conti, Chen, Schultz \& Edington 1999; Dorman 2000; Pearce et al 2004: Toohey, Borthwick \& Archer 2005) ranging from administration costs, turnover and absenteeism to equipment damage and disruption to work (Mylett \& Markey 2007). The way in which work is organised can affect employee well-being. Shift work, for example, common in the hotel industry, has often been associated with stress and relationship problems leading to stress (Wedderburn 2006). More generally, the work environment is a critical factor in the labour exit decision and there is general consensus that labour turnover impacts significantly on overall productivity (Blake 2006; CEOEA 2004; Hinkin \& Tracey 2008: Poulston 2006). As noted by Boxall. Macky and Rasmussen (2003), voluntary labour turnover represents one end of a continuum from retention at the other end with absenteeism and lateness in the middle. A recent Danish study confirmed that a third to a half of absenteeism is due to poor work environments (Lund et al. 2003). Costs associated with absenteeism. whether from injury or sickness. or lack of commitment to the job, can also be significant for an enterprise (Care NZ 2004: Morehead et al. 1997; Cully et al. 1999). Boxall et al. (2003) identified the work environment as a critical factor in the labour exit decision. More specifically, they identified amongst other factors, employee job satisfaction. the extent to which employees feel their contribution is valued. wellbeing and employer recognition of work-life balance as links between labour turnover and the work environment.

The concept of employee voice encompasses direct taskoriented practices, such as problem solving groups or semi autonomous teams, as well as representative structures like trade unions or joint consultative committees. An extensive literature argues that employee participation in decision-making improves motivation. communications and cooperation in the workplace, and hence, productivity. Employee participation has been recognised as a key ingredient in high performing work systems (Arthur 1994: Delaney \& Huselid 1996: Doucouliagos 1995; Meyer \& Topolnytsky 2000). No studies directly addressing these connections have been undertaken in New Zealand, however British and Australian studies (Walters 2004: Walters et al. 2005), have found that worker representation and consultation through committees similar to the New Zealand ones produced better outcomes in occupational health and safety than management acting alone. Similar studies have also suggested that trade union presence has a positive impact on health and safety outcomes (Fairbrother 1996; Bohle and Quinlan 2000; Saksvik and Quinlan 2003). Evidence indicates economic and social benefits in introducing improved health and safety measures via worker participation structures that regulate work environments. The potential benefits are decreases in lost-time injuries; workers' compensation costs and damaged goods (Brady, et al, 1997; Bohle \& Quinlan, 2000; Cox \& Cox, 1996).

Although recent surveys indicate that 50 per cent of New Zealand employees experience some form of representative participation in the workplace (Haynes et al., 2005) there is clearly a need for more New Zealandbased research leading to 'best practices' in this area. In particular, as the legal requirement to implement health and safety committees is relatively new in New Zealand there has been little research investigating the impact of the employee representative processes mandated under the 2002 Act. In Denmark there is a large degree of consensus regarding the effectiveness of representative employee participation however representative participation has rarely been researched in the context of productivity and employee well-being. The propensity to leave a job was mitigated by feelings of empowerment, opportunity to contribute to work organisation and a sense that employee contributions are valued by employers (Boxall et al 2003; DOL 2004). Representative forms of employee participation, such as delegates and committees under New Zealand's Health and Safety in Employment Amendment Act 2002, directly address this issue.

\section{Defining productivity and performance}

The project has adopted a multi-faceted definition of productivity and performance, for three main reasons. First, the limitations in standard definitions of productivity, in terms of application and interpretation are substantial (Black \& Lynch 2001; De Greef \& Van den Broek 2004; Herzog \& Morgan 1992; Mathew 2007; New Zealand Tourism Institute 2007; Theriou \& Chatzoglou 2008). Second, a huge degree of slippage between different terms that refer to the performance of an organisation has occurred in the productivity and related literature (Delaney \& Huselid 1996; Rosenberg \& Rosenstein 1980). Apart from productivity and performance, effectiveness, efficiency and profitability are also commonly referred to in the literature (Forth \& McNabb 2008), but these terms indicate different outcomes (Capelli \& Neumark 2001; Dobni, Ritchie \& Zerbe 2000; Fairris 2002; Mahoney 1988). Third, the traditional definition of productivity does not offer the comprehensive picture of organisational performance that consideration of a range of different indicators of performance does (Baptiste 2008; Becker \& Gerhart 1996; Levine \& D'Andrea Tyson 1990). Different 
organisations in different sectors also tend to use different measurements of performance.

This project therefore refers to productivity and performance, taking into account, where possible, traditional notions of productivity, profitability, return on capital and so on, as well as the performance measures which different sectors consider important for contextual reasons. Four proxies for performance at the workplace level have commonly been utilised: labour turnover, absenteeism, incidence of injury and occupational disease in the workforce, and the degree of training in an organisation. The first three of these proxies indicate costs or negative influences on productivity and performance, whereas training represents an investment with a potentially positive influence on productivity and performance. The project has also adopted these proxies because of their significance as discussed above.

\section{Methodology}

The project has adopted a multi-method case study approach targeting five key service industries which are present in both Denmark and New Zealand: hospitality, finance, information and communication technology (ICT), education, health, and food manufacturing. We have focused mainly on the service sector for three reasons. First, it has attracted less attention than manufacturing in research literature on productivity and health and safety, largely because manufacturing output is easier to measure for calculating labour productivity (Mathew 2007), and manufacturing produces easily recognised physical injury to a greater extent than service industries, where stress related disease is more prevalent, but also less obvious. Secondly, the service sector includes a substantial public sector in most countries, notably in our target industries of Education and Health. This enables some comparison between private and public sector practices which may affect outcomes in the relationships we are examining. Thirdly, the service sector is the major employer in modern developed market economies such as New Zealand and Denmark.

A total of 24 organisational case studies will be conducted: 12 each in New Zealand and Denmark and where possible one large and one medium sized organisation will be studied within each industry. The rationale for this is that size affects degree of formalisation of representative structures.

\section{Figure 2: Industries targeted in the research}

\begin{tabular}{|l|l|}
\hline Hospitality & 2 hotels \\
\hline Finance & 2 large bank branches \\
\hline ICT & 2 telecommunications providers \\
\hline Education & 2 secondary schools \\
\hline Health & 2 departments in hospital(s) \\
\hline Food Manufacturing & 1 confectionary manufacturer \\
\hline & 1 bread manufacturer \\
\hline
\end{tabular}

All organisations chosen as case studies have needed to meet the following criteria:

- they employ sufficiently large workforces for the mandated representative provisions of the New Zealand Health and Safety in Employment Amendment Act 2002 and Danish Work Environment Act 1975 (Harris 2004; Knudsen 1995);

- Organisations for each industry in each country will be chosen to represent those with absenteeism and/or labour turnover rates 20 per cent above and below the industry average.

\section{Figure 3: Research Questions}

1. What characterises employee participation in
establishments with good and less good working
environments?
2. What correlations are there between effective
employee participation, positive work environments
and good business outcomes?
3. What is best practice in employee participation as
an instrument in regulation of the work
environment?

The research questions are summarised in figure 3 and organisational and organisational data investigating them will be sought in three main areas:

1. Indicators of productivity/efficiency including data on organisational performance in the past two years

2. Indicators of wellness/well-being

3. Operation of participative structures, including health and safety committees, joint consultation committees, and cooperation committees.

Data gathered will include organisational documents and policy; organisational statistics such as absenteeism; semi-structured interviews with chief executive manager, human resource manager, senior employee representative and one other employee representative; survey of 20 employees from each organisation. This multi-method, multi-source approach increases the richness of the data, and with use of a triangulation process increases validity of the outcomes (Denzin \& Lincoln 2005; Gillham 2005).

\section{Conclusion}

This project will contribute to existing research by responding to several identified gaps. Most importantly it will provide information on the links and interaction between employee well being, participation and productivity which is a significant innovation introduced by this project. It will provide international comparison and particular insights into productivity in the service sector, which is a major employer and contributor to most modern developed market economies. Furthermore it is anticipated that this research will contribute to the 
literature by developing and testing new models and measures of productivity.

\section{References}

Akerlof, G. A., \& Yellen, J. L. (Eds). (1986). Efficiency Wage Models of the Labor Market. New York: Cambridge University Press.

Aldana, S. G. (2001). Financial impact of health promotion programs: A comprehensive review of the literature. American Journal of Health Promotion, 15, 5, 296-320.

Arthur, J. B. (1994). Effects of human resource systems on manufacturing performance and turnover. Academy of Management Journal, 37, 3, 670-687.

Baptiste, N. R. (2008). Tightening the link between employee wellbeing at work and performance. A new dimension for HRM. Management Decision. 46,2, 284-309.

Becker, B., \& Gerhart, B. (1996). The impact of human resource management on organizational performance: Progress and prospects. Academy of Management Journal, 49, 4, 779-801.

Bernard, E. (1995). Canada: Joint committees on occupational health and safety. In J. Rogers and W. Streeck (eds), Works Councils. Consultation, Representation, and Cooperation in Industrial Relations. Chicago: University of Chicago Press, 351-74.

Black, S. E., \& Lynch, L. M. (2001). How to Compete: The Impact of Workplace Practices and Information Technology on Productivity. The Review of Economics and Statistics, 83, 3, 434445.

Blake, R. (2006). Employee Retention: What Employee Turnover Really Costs Your Company. Retrieved from

www.webpronews.com/expertarticles/2006/07/24/ employee-retention-what-employee-turnoverreally-costs-your-company, accessed 27 May 2007.

Bohle, P. \& Quinlan, M. (2000). Managing Occupational Health and Safety: A Multidisciplinary Approach. Melbourne: Macmillan Publishing Australia.

Boxall, P., Macky, K. and Rasmussen, E. (2003). Labour Turnover \& Retention in New Zealand: The Causes and Consequences of Leaving and Staying with Employers. Asia Pacific Journal of Human Resources, 41, 2, 195-214.
Brady, W., Bass, J., Moser, R., Anstadt, G.W., Loeppke, R.R., \& Leopold, R. (1997) Defining total corporate health and safety costs significance and impact: Review and recommendations' Journal of Occupational \& Environmental Medicine, 39, 3, 224-231.

Burton, W. N., Conti, D. J., Chen, C.-Y. P., Schultz, A. B., \& Edington, D. W. (1999). The role of health risk factors and disease on worker productivity. Journal of Occupational \& Environmental Medicine October, 41, 10, 863. 877.

Cappelli, P., \& Neumark, D. (2001). Do "high performance" work practices improve establishment-level outcomes? Industrial and Labour Relations Review, 54, 4, 737-775.

Care NZ (2004), website: www.carenz.co.nz/workplace.htm, accessed 27 May 2007.

Council for Equal Opportunity Employment in Australia (CEOEA) (2004), accessed from www.eowa.gov.au 5 January 2004.

Chapman, L. (2005). Meta-evaluation of worksite health promotion economic return studies: 2005 update. American Journal of Health Promotion, 19, 16, 1 . 11.

Cox, S. and Cox, T. (1996) Safety Systems and People, Butterworth-Heinemann, Oxford.

Cully, M., Woodlands, S., O'Reilly, A., and Dix, G. (1999). Britain at Work. As depicted by the 1998 Workplace Employee Relations Survey. London: Routledge.

De Greef, M., \& Van den Broek, K. (2004). Quality of the Working Environment and Productivity. Research Findings and Case Studies. Belgium: European Agency for Safety and Health at Work.

Delaney, J. T., \& Huselid, M. A. (1996). The Impact of Human Resource Management Practices on Perceptions of Organizational Performance. Academy of Management Journal, 39, 4, 949-969.

Denzin, N. K., \& Lincoln, Y. S. (2005). Introduction: The Discipline and practice of qualitative research. In N. K. Denzin \& Y. S. Lincoln (Eds). The Sage Handbook of Qualitative Research (3rd ed). Thousand Oaks, CA: Sage Publications, 1-32.

Department of Labour. (2002). Employee participation systems factsheet. Wellington, New Zealand: Department of Labour. 
Department of Labour. (2004). The Workplace Productivity Challenge. Summary of the Report of the Workplace Productivity Working Group. Wellington: Department of Labour.

Department of Labour. (2006). Work-life Balance in New Zealand: A snapshot of employee and employer attitudes and experiences. Wellington: Department of Labour.

Department of Labour. (2008). Working Long Hours in New Zealand: A Profile of Long Hours Workers Using Data from the 2006 Census. Wellington: Department of Labour.

Dobni, D., Ritchie, J. R. B., \& Zerbe, W. (2000). Organizational values: The inside view of service productivity. Journal of Business Research, 47,2, 91-107.

Dorman, P. (2000). The Economics of Safety, Health, and Well-being at Work: An Overview. Geneva, Switzerland: International Labour Organisation.

Doucouliagos, C. (1995). Worker participation and productivity in labor-managed and participatory capitalist firms: A meta-analysis. Industrial and Labor Relations Review, 49, 1, 58-77.

Fairris, D. (2002). Are transformed workplaces more productively efficient? Journal of Economic Issues, 36, 3, 659-670.

Fairbrother, P. (1996). Organize and survive: Unions and health and safety - A case study of an engineering unionized workforce. Employee Relations, 18, 2, 5 - 88.

Forth, J., \& McNabb, R. (2008). Workplace performance: a comparison of subjective and objective measures in the 2004 Employment Relations Survey. Industrial Relations Journal, 39, 2, 104-123.

Gillham, B. (2005). Case Study Research Methods. London: Continuum.

Grawitch, M. J., Gottschalk, M., \& Munz, D. C. (2006). The path to a healthy workplace. A critical review linking healthy workplace practices, employee well-being, and organizational improvements. Consulting Psychology Journal: Practice \& Research Summer, 58, 3, 129-147.

Grawitch, M. J., Trares, S., \& Kohler, J. M. (2007). Healthy workplace practices and employee outcomes. International Journal of Stress Management, 14, 3, 275-293.
Hamalainen, P., Takala, J. and Saarela, K.L. (2006). Global estimates of occupational accidents. Safety Science, 44, 137 - 156.

Harris, P. (2004). From health and safety to employee participation? The impact of the New Zealand Health and Safety in Employment Amendment Act (2002). International Employment Relations Review, 10, 1, 1 - 12 .

Harter, J., Schmidt, F. L., \& Keyes, C. (2002). Wellbeing in the workplace and its relationship to business outcomes a review of the Gallup studies. In C. Keyes \& J. Haidt (Eds). Flourishing: The Positive Person and the Good Life. Washington D.C: American Psychological Association, 205224.

Haynes, P., Boxall, P. and Macky, K. (2005). Nonunion Voice and the Effectiveness of Joint Consultation on New Zealand. Economic and Industrial Democracy, 26, 2, 229-256.

Heller, F. (1998). Myth and Reality: Valediction. In F. Heller, E. Pusic, G. Strauss \& B. Wilpert. Organizational Participation. Myth and Reality. New York: Oxford University Press, 220-49.

Herzog, A. R., \& Morgan, J. N. (1992). Age and Gender Differences in the Value of Productive Activities. Research On Aging, 14, 2, 169-198.

Hinkin, T. and Tracey, J. (2000). The Cost of Turnover. Cornell Hotel and Restaurant Administration Quarterly, 41, 3, 14-21.

Iverson, F. and Riishøj, J. (2007). Development in productivity in Denmark. Danmarks Nationalbank Monetary Review. XLVI $/ 4^{\text {th }}$ Quarter. Denmark.

Jecchinis, C. (1997). Informal and statutory participation in Greece: General trends and two indicative cases. In R. Markey and J. Monat (eds). Innovation and Employee Participation Through Works Councils. International Case Studies. Aldershot: Avebury, 129-52.

Knudsen, H. (1995). Employee Participation in Europe. London: Sage.

Lamm, F. (2002). Occupational safety and health. In J. Deeks and E. Rasmussen. Employment Relations in New Zealand. Auckland:Pearson, 391-412.

Lau, R. (2000). Quality of work life and performance. An ad hoc investigation of two key elements in the service profit chain model. International Journal of Service, 11, 5, 422-437. 
Levine, D. L., \& D'Andrea Tyson, L. (1990). Participation, productivity, and the firm's environment. In A. S. Blinder (Ed.), Paying for Productivity. A Look at the Evidence. Washington, D.C.: The Brookings Institution, 183-243

Liddicoat, L. (2003). Stakeholder Perceptions of Family-Friendly Workplaces: An Examination of Six New Zealand Organisations Asia Pacific Journal of Human Resources, 41, 3, 354-370.

Lund, T., Jensen, C., Nielsen, M.L. and Borg, V. (2003). Sygefravaer I et arbejdsmiljóperspektiv (Absenteeism in a Work Environment Perspective). Copenhagen:

Arbejdsmiljǿinstituttet.

Macky, K., and Boxall, P. (2008). High-involvement work processes, work intensification and employee well-being: A study of New Zealand worker experiences. Asia Pacific Journal of Human Resources. 46,1, 38-55.

Mahoney, T. A. (1988). Productivity defined: The relativity of efficiency, effectiveness, and change. In J. P. Campbell \& R. J. Campbell (Eds), Productivity in organizations. New Perspectives from Industrial and Organizational Psychology. San Francisco.: Jossey-Bass Publishers, 13-39.

Markey, R. (2001). Introduction: Global patterns of participation. In Markey, R., Gollan, P., Hodgkinson, A. Chouraqui, A. and Veersma, U. (eds). Models of Employee Participation in a Changing Environment: Diversity and Interaction. Aldershot \& Burlington: Ashgate Publishing Limited, 3-22.

Markey, R. \& Shulruf, B (2008). Effects of workplace practices on profitability: evidence from New Zealand. Paper presented at 6th Regional Congress for the Americas of the International Industrial Relations Association, Buenos Aires.

Mathew, J. (2007). The Relationship of Organisational Culture with Productivity and Quality. A Study of Indian Software Organisations. Employee Relations, 29, 6, 677-695.

Meyer, J., \& Topolnytsky, L. (2000). Building and maintaining employee commitment: implications for HRM policy and practice. In A. Travaglione \& V. Marshall (Eds). Human Resource Strategies: An Applied Approach. Sydney: McGraw-Hill.

Morehead, A., Steele, M., Alexander, M., Stephen, K. and Duffin, L. (1997). Changes at Work. The 1995 Australian Workplace Industrial Relations Survey. Melbourne: Longman.
Mylett, T. and Markey, R. (2007). Worker Participation in OHS in NSW (Australia) \& New Zealand: Methods \& Implications. Employment Relations Record, 7, 2, 15-31.

National Occupational Health and Safety Advisory Committee (2006). The Economic and Social Costs of Occupational Disease and Injury in New Zealand. Technical Report no. 4, Wellington, accessed at www.nohsac.govt.nz/techreport4, 27 May 2007.

New Zealand Tourism Research Institute. (2007). Food \& Beverage Service Sector Productivity Study. Wellington: Department of Labour.

OECD. (2005). OECD Observer Policy Brief: Economic Survey of Denmark. Paris: OECD.

Oxenburgh, M., Marolow, P. and Oxenburgh, A. (2004). Increasing Productivity and Profit through Health and Safety. The Financial Returns from a Safe Working Environment $\left(2^{\text {nd }}\right.$ ed.). Boca Raton, FL: CRC Press.

Patterson, M., West, M., Lawthom, R., \& Nickell, S. (1997). Impact of People Management Practices on Business Performance. Sheffield: University of Sheffield.

Pearce, N., Dryson, E., Feyer, A. and McCracken, S. (2004). The Burden of Occupational Disease and Injury in NZ: Report to the Associate Minister of Labour. Wellington: National Health and Safety Committee.

Pocock, B. (2003). The work/life collision: What work is doing to Australians and what to do about it. Leichhardt, Australia: The Federation Press.

Poulston, J. (2006). Ethical Issues and Workplace Problems in Commercial Hospitality: a New Zealand Perspective. Unpublished doctoral thesis. Auckland: AUT University.

Pringle, J., \& Tudhope, J. (1996). Family Friendly Policies: The Experiences of Three New Zealand Companies. Asia Pacific Journal of Human Resources, 34, 3, 77-89.

Quinlan, M., Mayhew, C. and Bohle, P. (2001). The global expansion of precarious employment, work disorganisation and occupational health: A review of recent research. International Journal of Health Services, 31, 2, 335-414.

Rosenberg, R. D., \& Rosenstein, E. (1980). Participation and Productivity: An Empirical Study. Industrial and Labour Relations Review, 33, 3, 355-367. 
Saksvik, P.O., \& Quinlan, M. (2003). Regulating systematic occupational health and safety management: comparing the Norwegian and Australian experience. Relations Industrielles, 58, 1, 33-56.

Strachan, G., \& Burgess, J. (1998). The "family friendly" workplace Origins, meaning and application at Australian workplaces. International Journal of Manpower, 19,4, 250265.

Tetrick, L. E., \& Quick, J. C. (2001). Prevention at work: Public health in occupational settings. In J. C. Quick \& L. E. Tetrick (Eds), Handbook of occupational health psychology. Washington DC: American Psychological Association, 3-17.

Theriou, G. N., \& Chatzoglou, P. D. (2008). Enhancing Performance Through Best HRM Practices, Organizational Learning and Knowledge Management. A Conceptual Framework. European Business Review, 20, 3, 185-207.

Toohey, J., Borthwick, K., \& Archer, R. (2005). Occupational Health and Safety in Australia: A Management Guide. Melbourne: Thomson.

Van Buren, M. (2002). From cost to investment: Workplace learning has new significance. Employment Relations Today, 29, 1, 63-72.

Walters, D. (2004). Workplace arrangements for worker participation in OHS. In E. Bluff, N. Gunningham \& R. Johnstone (Eds). OHS Regulation for a Changing World of Work. Sydney: Federation Press, 68 - 93.

Walters, D., Dalton, A. and Gee, D. (1993). Worker and Trade Union Representation on Health and Safety in Europe: The Theory, the Practice and the Potential. Brussels: Trade Union Technical Bureau.

Walters, D., Nichols, T., Connor, J., Tasiran, A. and Cam, S. (2005). The role and effectiveness of safety representatives in Influencing workplace health and safety. Research Report 363. London: UK Health and Safety Executive.

Wedderburn, A. (2006). Shift Work \& Health, European Foundation for the Improvement of Living \& Working Conditions, online report, accessed 27 May 2007: www.eurofound.europa.eu/publications/htmlfiles/e f0009.htm.

Yasbek, P. (2004). The business case for firm-level work-life balance policies: a review of the literature. Wellington: Department of Labour.

\section{Authors}

Ray Markey

Professor School of Business - Business Research

Auckland University of Technology

Private Bag 92006

Auckland 1142

Ray.Markey@aut.ac.nz

Candice Harris

Senior Research Lecturer

School of Business - Management

Auckland University of Technology

Private Bag 92006

Auckland 1142

Candice.Harris@aut.ac.nz

Felicity Lamm

Associate Professor

School of Business - Management

Auckland University of Technology

Private Bag 92006

Auckland 1142

Felicity.Lamm@aut.ac.nz

\section{Stefan Kesting}

Senior Research Lecturer

School of Business - Economics

Auckland University of Technology

Private Bag 92006

Auckland 1142

Stefan.Kesting@aut.ac.nz

Katherine Ravenswood

School of Business - Business Research

Auckland University of Technology

Private Bag 92006

Auckland 1142

Katherine.Ravenswood@aut.ac.nz

Gay Simpkin

School of Business - Business Research

Auckland University of Technology

Private Bag 92006

Auckland 1142

Gay.Simpkin@aut.ac.nz

David Williamson

Senior Lecturer

School of Hospitality and Tourism

Auckland University of Technology

Private Bag 92006

Auckland 1142

David.Williamson@aut.ac.nz 